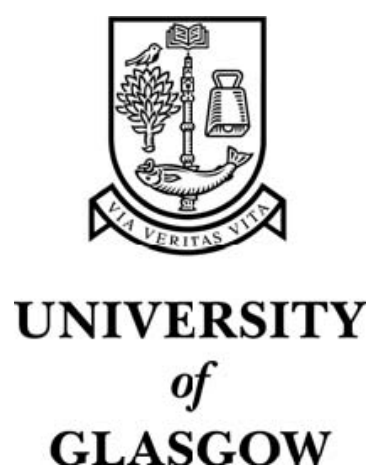

Jones, E. and Danbolt, J. (2005) Empirical evidence on the determinants of the stock market reaction to product and market diversification announcements. Applied Financial Economics 15(9):pp. 623-629.

http://eprints.gla.ac.uk/3686/ 


\section{Empirical evidence on the determinants of the stock market reaction to product and market diversification announcements}

Edward A.E. Jones* and Jo Danbolt**

* European Business Management School, University of Wales Swansea, UK

** Department of Accounting and Finance, University of Glasgow, UK

Keywords: Capital Investment, Investment Announcements, New Product Announcements, Event Study

JEL: $\quad$ G30, G31

Running title: Product-market diversification announcements and stock prices

Correspondence: Edward Jones, European Business Management School, University of Wales Swansea, Singleton Park, Swansea, Wales, SA1 6RY. e.a.e.jones@swan.ac.uk

Acknowledgements:

We are grateful to Ian Hirst, Mark Taylor (the editor) and an anonymous referee for valuable comments on previous versions of this paper. The responsibility for any remaining errors rests fully with the authors. 
Empirical evidence on the determinants of the stock market reaction to product and market diversification announcements

\begin{abstract}
The announcement of product and market diversification projects lead to significant abnormal returns of $1.1 \%$. However, the gains are higher for new products than for new markets, and for companies with high price-earnings ratios and low (or zero) dividend yields.
\end{abstract}

Running title: Product and Market Diversification Announcements 


\section{Empirical evidence on the determinants of the stock market reaction to product and market diversification announcements}

\section{Introduction}

In this paper, we examine the level of abnormal returns arising when a company announces projects that will result in product or market diversification, and the influence of company and project specific variables on the stock market reaction to such corporate announcements.

The sample is made up of 88 product or market diversification (PM) investment announcements from the UK Stock Exchange Regulatory News Service registered between September 1991 and September 1996. The sample includes projects that involve the commitment of resources to new product launches or the marketing of current products in new markets overseas ${ }^{\mathrm{i}}$. Entering new markets or developing new projects may involve relatively high risk, although the risk may differ between these categories of investments. Companies may choose to manage the risk of the new investment by entering into partnership with another firm. Consequently, our sample is subdivided to account for differential reactions to new products, expansion projects and joint ventures. We also test for the influence of company size, priceearnings ratio and dividend yield on the level of abnormal returns.

We find product/market diversification projects to be associated with significant positive abnormal returns of $1.1 \%$ on the day of announcement. The gains are higher for investments in new markets than in new products, and for companies with high price-earnings ratios and low (or zero) dividend yields - characteristics of companies with high growth opportunities. 
The remainder of the paper is organised as follows. We first consider the previous empirical literature on investment announcements. Then, we examine abnormal returns for the set of PM announcements. This is followed by a cross-sectional analysis of the market reaction to PM announcements with a set of project and company variables, while our conclusions are contained in the final section.

\section{Prior evidence on the stock market reaction to product and market diversification announcements}

While various studies have provided evidence of differential stock price performance for different types of capital investment announcements, there is only limited prior literature on stock price reactions to the specific category of new product or market diversification investments.

Woolridge and Snow (1990), based on US data, found the stock market on average to react positively to investment announcements, with new product/market diversification investment announcements associated with mean abnormal returns of 0.69\%. Chaney and Devinney (1992) similarly found positive stock price reactions to new product or service innovations by US companies. They identified an excess return of $0.6 \%$ for a three-day event window centred on the announcement date. Of particular interest is their finding that the stock market reaction was higher for truly new products compared to the expansion of existing products. Their results contrast with an early US study by Eddy and Saunders (1980) who found no significant return to new product announcements using monthly returns. More recently, Chen and Ho (1997) examined the market response to product-strategy announcements in Singapore, finding a two-day cumulative abnormal return of $0.65 \%$. Jones et al. 
(2004) analysed the stock market reaction to investment announcements in the UK, finding mean abnormal returns on the day of the announcement of $0.87 \%$. However, they further found that investments that 'create' future investment opportunities (including research and development and product/market diversification projects) resulted in significantly higher abnormal returns than investments that 'exercise' investment opportunities (asset expenditure or cost reduction projects), with mean abnormal returns of $2.01 \%$ and $0.23 \%$, respectively.

In this paper, we add to prior literature by analysing the stock market reaction to product and market diversification projects in the UK, and test the impact of company characteristics on the level of abnormal returns.

\section{Data characteristics and average abnormal returns}

Information on PM announcements was collected from the Financial Times Extel Database, which includes all official announcements made by UK listed companies through the Stock Exchange Regulatory News Service. New product and market expansion announcements were identified between September 1991 and September 1996. The initial sample consisted of 132 announcements. After deleting announcements made concurrently with other corporate announcements (within the period from day $t-1$ to $t+1$, where $t$ refers to the day of the investment announcement) and two outliers, we are left with a final sample of 88 observations. Announcements were only included if product or market diversification was the primary stated purpose of the project. Announcements were then subdivided into new products, market expansion projects, and joint ventures ${ }^{\mathrm{ii}}$. Stock price and fundamental information was collected from Datastream. 
We report the abnormal returns on the day of the announcement using the marketadjusted return model, although the results are robust to alternative model specifications $^{\mathrm{iii}}$. Brown and Warner (1985) showed the market-adjusted returns method to be as efficient as other models in detecting abnormal returns associated with specific events. In addition, since this study uses daily data, the adjustment to index returns, which are small, is negligible. The market-adjusted returns $(\varepsilon)$ are calculated using the following equation:

$$
\varepsilon_{\mathrm{it}} \quad=\quad \mathrm{R}_{\mathrm{it}}-\mathrm{R}_{\mathrm{mt}}
$$

where $\varepsilon_{\mathrm{it}}=$ abnormal return on the share $\mathrm{i}$ on day $\mathrm{t}, \mathrm{R}_{\mathrm{it}}=$ return on share $\mathrm{i}$ on day $\mathrm{t}$, and $\mathrm{R}_{\mathrm{mt}}=$ return on the FT All Share Index ${ }^{\text {iv }}$ on day t. Both t-tests and nonparametric tests are used to test abnormal performance due to the small sample size, especially when the data is sub-categorised.

\section{$\underline{\text { Insert table } 1 \text { here }}$}

The abnormal returns, calculated using the market-adjusted return method, are given in table 1. As discussed further in section 4 below, prior literature suggests the market may react differently to the announcement of joint ventures compared to single company investments. We therefore report the results both for the full sample of PM project announcements and for the sub-samples of joint ventures and single company investments. The average abnormal return is $1.1 \%$ (significant at the $1 \%$ level) for the sample as a whole, which is notably larger than the $0.69 \%$ abnormal return for PM projects in the US calculated by Woolridge and Snow (1990) and the 0.6\% three-day abnormal return identified by Chaney and Devinney (1992). While 
lower than the mean, the median abnormal return for our sample (at $0.4 \%$ ) is also statistically significant.

For the subset of projects that were undertaken with a joint venture partner company (JV), the mean (median) abnormal return is $0.4 \%(0.0 \%)$, which is not significant using either a t-test or the Wilcoxon test. The stock market reaction to projects undertaken by companies as a joint venture is significantly lower than that for projects undertaken without a partner (mean $1.8 \%$, median $0.7 \%$ ). This suggests that the market reacts less favourably to PM investment projects where the returns (and risks) are shared with another company.

The sample is further subdivided into projects involving new projects (NP) and market expansion (EX). The new products category exhibits a mean (median) market-adjusted return of $1.7 \%(0.6 \%)$, significant at the $1 \%$ level. The category of market expansion projects for the whole sample only exhibits an abnormal return of $0.4 \%(-0.2 \%)$, which is not significant using either a t-test or a Wilcoxon text. The difference in abnormal returns between these categories is statistically significant using an independent samples t-test and a non-parametric Mann-Whitney U test, indicating that the market reacts more positively to new product announcements than to the expansion into new markets. For both the new product and expansion subsamples, we find returns to be lower for joint ventures than for single company investments.

\section{Cross-Sectional Analysis}

We next analyse whether the stock market reaction to product or market diversification announcements varies with the characteristics of the transaction or 
the firm making the investment ${ }^{\mathrm{v}}$. McConnell and Nantell (1985), Keown et al., (1999) and Jones and Danbolt (2004) all found the stock market reactions to investment announcements to vary with company size, with investments by small companies being associated with larger abnormal returns. Although Burton et al. (1999) found no impact of company size, we hypothesise that the level of abnormal returns will be negatively related to company size ${ }^{\mathrm{vi}}$.

Burton et al. (1999) argued that the market might react more favourably to JVs than to single-company investments when investments are highly risky. They found JV announcements to be associated with small but significant positive abnormal returns, as did McConnell and Nantell (1985), Woolridge and Snow (1990) and Jones and Danbolt (2004). Jones et al. (2004) found JVs to be associated with higher abnormal returns than single company investments, although Chung et al. (1993) found international JVs to be associated with negative abnormal returns. While the extant literature is somewhat inconclusive, based on the theoretical predictions of Burton et al., we hypothesise that JVs will have a positive impact on the level of abnormal returns.

Finally, we consider the impact of growth opportunities on the level of abnormal returns. It can be hypothesised that the stock market will react more favourably to new investment announcements by firms with valuable growth opportunities than for other companies, although in their analysis of UK investment announcements Burton et al. (1999) found no significant impact of the level of growth opportunities on the level of abnormal returns. Still, we include two proxies for growth opportunities, and hypothesise that companies with high price-earnings ratios or low 
dividend yields will experience more positive stock market reactions to product or market diversification investment announcements than other firms.

The cross-sectional analysis was undertaken using a linear regression model ${ }^{\mathrm{vii}}$. The relationship examined is as follows:

$$
\varepsilon_{\mathrm{i}}=\mathrm{f}(\mathrm{LOGS}, \mathrm{JV}, \mathrm{PE}, \mathrm{DY}, \mathrm{PR})
$$

where $\varepsilon_{\mathrm{i}}=$ abnormal return on the day of the product/market diversification announcement, LOGS = log of the market capitalisation of the company on day $\mathrm{t}-1$, $\mathrm{JV}=$ dummy variable taking a value of 1 for joint ventures, $\mathrm{PE}=$ price-earnings ratio, and DY = dividend yield. We also include a dummy variable to control for whether the announcement is of a product or market diversification investment (PR), which takes a value of 1 for new product launches. Descriptive statistics for the independent variables are contained in table 2.

\section{Insert table 2 here}

Most notable from table 2 is the very high range for the Price-Earnings ratio. It is this figure which directed our attention towards companies with low earnings compared to the price, indicating high growth potential, and consequently to dividend policy. The regression models presented in table 3 use three dependent variables - these represent the market-adjusted return for the whole sample (PM), new products (NP) and expansion projects (EX). ${ }^{\text {viii }}$ 
The primary finding of table 3 is that, consistent with our hypothesis, the log of company size (LOGS) exhibits a negative and significant coefficient in all models in which it is included. It is not just significant for the sample as a whole, but also for the set of new product investments, for which the model explains $15.9 \%$ of the variation of abnormal returns. It would appear that product diversification announcements are recognised by the market as being of greater significance for smaller firms. However, our evidence suggests that size does not have a significant impact on expansion projects.

In table 1 we report abnormal returns to be higher for new products, and lower for joint ventures, than for the sample as a whole. However, as can be seen from table 3, neither the new product announcement dummy nor the joint venture dummy is found to be significant at the $5 \%$ level or better in any of the models once the LOGS variable is included. The abnormal return to new product announcements is related to the log of company size, but not to the PE ratio or the dividend yield (DY).

The most interesting findings in table 3 relate to the coefficients and significance of the dividend yield and the price-earnings ratio. Due to a predictably high correlation between the DY and PE variables (Pearson correlation $=-0.265$, Spearman correlation coefficient $=-0.414$ ), only one or the other is included in any given model. The results for the dividend yield suggest that there is a negative but small adjustment to abnormal return depending on the dividend yield. The dividend yield is only significant for models of the whole sample and not for any of the individual subcategories. The results imply that markets react negatively to product/market diversification announcements for companies with a high dividend yield. 
We can speculate that such an effect may be the result of short-termism due to an expectation that short-term dividends may be curtailed to pay for the new investment. An alternative interpretation, however, of the impact of dividends on the level of abnormal returns, relates to the growth characteristics of the firm. In their analysis of the dividend patterns of US companies, Fama and French (2001) found companies with high levels of growth opportunities and investment activity to be significantly less likely to pay dividends than other firms. Growth firms tend not only to have low dividend yield, but also to have high price-earnings multiples. We find the PE variable to be positive in all models in which it is included and significant at the $1 \%$ level. It would appear from our data that when the PE ratio is high, the market rewards product/market diversification announcements. This seems to be the case particularly for projects to expand current operations into new markets. These results appear to be driven by the cases where the PE ratio gets very high and when the dividend is zero. Removal of high PE ratios and zero dividends result in a loss of significance in all cases. As a result an additional variable is added to the analysis. DYZERO is a dummy variable taking a value of 1 when no dividend is paid.

Consistent with the findings for the US by Fama and French (2001), companies with zero dividends tend to also have high valuations, and we find non-dividend paying firms to have higher price-earnings ratios than the dividend payers. There were 18 cases of zero dividends in the sample. The DYZERO variable is significant in all models in which it is included. For the sample as a whole and for the subset of new product announcements, DYZERO is significant with an adjusted $\mathrm{R}^{2}$ of $19.6 \%$ for the sample as a whole and $22.6 \%$ for the sub-sample of new product investments. 
The significance of LOGS disappears when DYZERO is included, suggesting that a key variable in the valuation of product/market diversification announcements is whether or not the company pays a dividend. The stock market thus reacts more favourably to PM projects when companies have high PE ratios and low - preferably zero - dividends. Zero dividends are, as argued by Fama and French (2001), an increasingly common characteristic of high growth firms. The market thus appears to differentiate between companies with valuable growth opportunities and those without in their reaction to the announcement of new product or market diversification investments.

The market expansion projects in our sample appear to represent investment options that are exercised by companies and as such there is no evidence that announcements of expansion projects provide an abnormal return. Investments in new products, which lead to higher (and significant) market-adjusted returns, perhaps create additional growth options. Our evidence can thus be interpreted to provide support for the view expressed by Dixit and Pindyck (1994) that "if financial market participants understand the nature of the options correctly, they will place greater value on the investments that create options, and they will be more hesitant to finance those that exercise options.” (Dixit and Pindyck, 1995, p113).

\section{Conclusions}

This paper has examined the stock market reaction to product or market diversification (PM) investment announcements. We find that information regarding PM projects contain significant new information about the company's future earnings, resulting in average abnormal returns of $1.1 \%$ on the announcement day. 
However, new product announcements result in significantly higher abnormal returns $(1.7 \%)$ compared to the entry into new markets $(0.4 \%)$.

The cross-sectional analysis reveals a significant relationship between company size and the market-adjusted returns for the sample as a whole, for new product announcements, and for joint ventures. The stock market reaction was more favourable for companies with low dividend yields and high price earnings ratios. Further analysis revealed that these results are attributable by zero dividend paying companies, and that the market responded favourably to announcements of productmarket diversification by these firms. This would be consistent with the market reacting more favourably to investments by companies with high growth opportunities. 


\section{Bibliography}

Brown, S.J. and Warner, J.L., (1985). 'Using daily stock returns: The case of event studies', Journal of Financial Economics, 14, pp. 3-31

Burton, B.M., Lonie A.A., and Power D.M., (1999). 'The stock market reaction to investment announcements: The case of individual capital expenditure projects', Journal of Business Finance \& Accounting, Jun/Jul, 26, 5/6, pp. 681-709.

Chan, S.H., Martin, J.D. and Kensinger, J.W., (1990). 'Corporate research and development expenditures and share value’, Journal of Financial Economics, 26, pp. 255-276.

Chaney, P.K. and Devinney, T.M., (1992). 'New Product Innovations and Stock Price Performance', Journal of Business Finance and Accounting, 19, 5, September, pp. 677-695.

Chen, S.S. and Ho, K.W., (1997). 'Market response to product-strategy and capital expenditure announcements in Singapore: investment opportunities and free cash flow’, Financial Management, 26, 3, Autumn, pp82-88.

Chung, I.L., Koford, K.J. and Lee, I., (1993). 'Stock Market Views of Corporate Multinationalism: Some Evidence from Announcements of International Joint Ventures', The Quarterly Review of Economics and Finance, 33, 5, 275-293.

Dixit, A.K. and Pindyck, R.S., (1995). 'The options approach to capital investment', Harvard Business Review, May-June, pp. 105-115.

Eddy, A. and Saunders, G., (1980). 'New Product Announcements and Stock Prices’, Decision Sciences, 11, pp. 90-97. 
Fama, E.F., and French, K.R., (2001). 'Disappearing Dividends: Changing Firm Characteristics or Lower Propensity to Pay?', Journal of Financial Economics, 60, 1, April, pp. 3-43.

Gourlay, A., and Seaton, J., (2004). 'The Determinants of Firm Diversification in UK Quoted Companies’, Applied Economics, 36, 18, pp. 2059-2071.

Jones, E., and Danbolt, J., (2004). 'Joint Venture Investments and the Market Value of the Firm', Applied Financial Economics, 14, 18, pp. 1325-1331.

Jones, E., Danbolt, J., and Hirst, I., (2004). 'Company Investment Announcements and the Market Value of the Firm', European Journal of Finance, 10, 5, October, pp. 437-452.

Keim, D., (1983). 'Size-Related Anomalies and Stock Return Seasonality: Further Empirical Evidence’, Journal of Financial Economics, 12, June, pp. 13-32.

Keown, A. J., Laux, P.A., and Martin, J.D., (1999). 'The Information Content of Corporate Investment Announcements: The Case of Joint Ventures', Working Paper Series, www.ssrn.com.

McConnell, J. and Muscarella, C., (1985). 'Corporate capital expenditure decisions and the market value of the firm', Journal of Financial Economics, 14, pp. 399-422.

McConnell, J. and Nantell, T., (1985). 'Corporate Combinations and Common Stock Returns', Journal of Finance, 15, 519-536.

Strong, N., (1992). 'Modelling abnormal returns: A review article', Journal of Business Finance and Accounting, 19, June, pp. 533-553.

Woolridge, J.R. and Snow, C., (1990). 'Stock market reaction to strategic investment decisions’, Strategic Management Journal, 11, 5, September, pp. 353-363. 
Table 1

Market-adjusted returns for Product Market investment announcements and subcategories

\begin{tabular}{lcccccccc}
\hline & $\mathrm{n}$ & Mean & Median & Stdev. & Min & Max & Q1 & Q3 \\
\hline All & 88 & $0.011^{* * *}$ & $0.004^{* * *}$ & 0.028 & -0.071 & 0.108 & -0.005 & 0.020 \\
JV & 46 & 0.004 & 0.000 & 0.023 & -0.071 & 0.093 & -0.006 & 0.011 \\
SV & 42 & $0.018^{* * *}$ & $0.007^{* * *}$ & 0.031 & -0.024 & 0.108 & -0.002 & 0.027 \\
\hline NP & 47 & $0.017^{* * *}$ & $0.006^{* * *}$ & 0.028 & -0.024 & 0.108 & -0.001 & 0.034 \\
NP-JV & 19 & 0.008 & 0.005 & 0.019 & -0.019 & 0.048 & -0.005 & 0.014 \\
NP-SV & 28 & $0.022^{* * *}$ & $0.014^{* * *}$ & 0.031 & -0.024 & 0.108 & 0.000 & 0.050 \\
\hline EX & 41 & 0.004 & -0.002 & 0.027 & -0.071 & 0.099 & -0.006 & 0.008 \\
EX-JV & 27 & 0.001 & -0.003 & 0.026 & -0.071 & 0.093 & -0.006 & 0.009 \\
EX-SV & 14 & 0.009 & 0.002 & 0.028 & -0.016 & 0.099 & -0.005 & 0.009 \\
\hline
\end{tabular}

Notes: All represents the whole sample, $\mathrm{JV}=$ projects undertaken with a partner, $\mathrm{SV}=$ projects undertaken without a partner, NP = new product launch, and EX = expansion projects. $\mathrm{n}$ refers to the sample size. ${ }^{* * *}$ indicates a significant t-test (mean) and Wilcoxon test (median) at the $1 \%$ level. 
Table 2

Descriptive Statistics

\begin{tabular}{lcrrrrrrr}
\hline & $\mathrm{n}$ & \multicolumn{1}{c}{ Mean } & Median & Stdev. & Min & Max & \multicolumn{1}{c}{ Q1 } & \multicolumn{1}{c}{$\mathrm{Q} 3$} \\
\hline Size & 88 & 3067.81 & 600.17 & 5319.97 & 6.26 & 25269.68 & 80.73 & 3980.75 \\
LogSize & 88 & 6.34 & 6.40 & 2.18 & 1.83 & 10.14 & 4.39 & 8.29 \\
PE & 88 & 31.88 & 15.60 & 78.55 & 3.90 & 567.80 & 12.13 & 23.30 \\
DY & 88 & 3.26 & 3.38 & 2.58 & 0.00 & 12.66 & 0.74 & 5.05 \\
\hline
\end{tabular}

Notes: Size $=$ Market capitalisation of the company (expressed in $£$ millions), LogSize $=$ the $\log$ of the market capitalisation, $\mathrm{PE}=$ price-earnings ratio, and DY = dividend yield. 
Table 3

Regressions of abnormal returns

\begin{tabular}{|c|c|c|c|c|c|c|c|c|c|c|c|}
\hline & $\mathrm{N}$ & $\mathrm{C}$ & LOGS & PR & JV & DY & $\mathrm{PE}$ & DYZERO & $\mathrm{R}^{2}$ & Adj. $\mathrm{R}^{2}$ & $\mathrm{~F}$ \\
\hline PM & 88 & $\begin{array}{c}0.035 \\
(0.001)\end{array}$ & $\begin{array}{l}-0.263 \\
(0.012)\end{array}$ & $\begin{array}{c}0.150 \\
(0.141)\end{array}$ & & $\begin{array}{l}-0.206 \\
(0.047)\end{array}$ & & & 0.181 & 0.152 & $\begin{array}{c}6.206 \\
(0.001)\end{array}$ \\
\hline PM & 88 & $\begin{array}{c}0.023 \\
(0.017)\end{array}$ & $\begin{array}{l}-0.003 \\
(0.009)\end{array}$ & $\begin{array}{c}0.010 \\
(0.068)\end{array}$ & & & $\begin{array}{c}0.000 \\
(0.002)\end{array}$ & & 0.232 & 0.204 & $\begin{array}{l}8.441 \\
(0.000)\end{array}$ \\
\hline PM & 88 & $\begin{array}{c}0.042 \\
(0.000)\end{array}$ & $\begin{array}{l}-0.004 \\
(0.006)\end{array}$ & & & $\begin{array}{l}-0.002 \\
(0.032)\end{array}$ & & & 0.160 & 0.140 & $\begin{array}{c}8.093 \\
(0.001)\end{array}$ \\
\hline PM & 88 & $\begin{array}{c}0.031 \\
(0.000)\end{array}$ & $\begin{array}{l}-0.004 \\
(0.004)\end{array}$ & & & & $\begin{array}{c}0.000 \\
(0.003)\end{array}$ & & 0.200 & 0.181 & $\begin{array}{l}10.645 \\
(0.000)\end{array}$ \\
\hline PM & 88 & $\begin{array}{c}0.042 \\
(0.000)\end{array}$ & $\begin{array}{l}-0.003 \\
(0.026)\end{array}$ & & $\begin{array}{l}-0.009 \\
(0.136)\end{array}$ & $\begin{array}{l}-0.002 \\
(0.034)\end{array}$ & & & 0.182 & 0.153 & $\begin{array}{c}6.232 \\
(0.001)\end{array}$ \\
\hline PM & 88 & $\begin{array}{c}0.032 \\
(0.000)\end{array}$ & $\begin{array}{l}-0.003 \\
(0.017)\end{array}$ & & $\begin{array}{l}-0.009 \\
(0.127)\end{array}$ & & $\begin{array}{c}0.000 \\
(0.003)\end{array}$ & & 0.222 & 0.194 & $\begin{array}{c}8.002 \\
(0.000)\end{array}$ \\
\hline PM & 88 & $\begin{array}{c}0.005 \\
(0.108)\end{array}$ & & & & & & $\begin{array}{c}0.032 \\
(0.000)\end{array}$ & 0.205 & 0.196 & $\begin{array}{l}22.171 \\
(0.000)\end{array}$ \\
\hline NP & 47 & $\begin{array}{c}0.046 \\
(0.000)\end{array}$ & $\begin{array}{l}-0.005 \\
(0.003)\end{array}$ & & & & & & 0.178 & 0.159 & $\begin{array}{c}9.727 \\
(0.003)\end{array}$ \\
\hline NP & 47 & $\begin{array}{c}0.009 \\
(0.041)\end{array}$ & & & & & & $\begin{array}{c}0.031 \\
(0.000)\end{array}$ & 0.243 & 0.226 & $\begin{array}{l}14.439 \\
(0.000)\end{array}$ \\
\hline EX & 41 & $\begin{array}{c}-0.002 \\
(0.683)\end{array}$ & & & & & $\begin{array}{c}0.000 \\
(0.000)\end{array}$ & & 0.315 & 0.298 & $\begin{array}{l}17.949 \\
(0.000)\end{array}$ \\
\hline $\mathrm{EX}$ & 41 & $\begin{array}{c}0.001 \\
(0.785)\end{array}$ & & & & & & $\begin{array}{c}0.029 \\
(0.037)\end{array}$ & 0.107 & 0.084 & $\begin{array}{c}4.660 \\
(0.037)\end{array}$ \\
\hline
\end{tabular}

Notes: This table represents the results obtained from regressing event day market-adjusted returns on a set of company/project data. PM = market-adjusted return on day $\mathrm{t}$ for all product/market diversification announcements, $\mathrm{NP}=$ market-adjusted return on day $\mathrm{t}$ for new product announcements, EX = marketadjusted return on day $\mathrm{t}$ for expansion projects, $\mathrm{N}=$ no. of observations, $\mathrm{C}=$ Constant, LOGS $=$ the log of the market capitalisation, PR $=$ new product dummy, JV = joint venture dummy, DY = dividend yield, PE = price-earnings ratio, DYZERO = a dummy variable representing no dividend payment. The significance of the t-test of each variable is given underneath in parentheses. F indicates the F-statistic. The significance of F is given under the F-statistic in parentheses. No autocorrelation was detected for any of the models presented. 


\section{Notes}

${ }^{\mathrm{i}}$ New product areas would include new products or product improvements which might be considered as 'next generation' and consequently compete in a different market situation to current products.

ii The joint venture category overlaps the other two subcategories.

iii The abnormal returns were also calculated using the market model, a trade-to-trade adjusted market model, and a trade-to-trade adjusted market adjusted returns model. Given the short event window, the impact of alternative models on the levels of abnormal returns is minimal, although the sample sizes are reduced for these alternative models, due to their additional data requirements. We examine abnormal returns for the days $t-3$ to $t+3$ and find that the only significant abnormal performance is identified on day t, the day of the announcement, and that the abnormal return on day $\mathrm{t}$ is significantly different to each day before and after the announcement. Thus for our calculations we examine a one-day abnormal return for the day of the announcement.

iv The use of alternative market indices was examined but had a minimal impact since abnormal returns were calculated on a daily basis.

v See Gourlay and Seaton (2004) for a discussion of the characteristics of UK diversifying companies.

vi Jones et al., 2004 suggests project size relative to the size of the company may also be a major determinant of the level of abnormal returns, although Woolrdige and Snow (1990) find project size to have little impact. This variable can only be calculated for 20 observations in our sample, due to missing information on project size. Additional untabulated tests revealed the coefficient for project size relative to 
company size to be positive, as predicted, although not statistically significant, due to the small sample when this variable was included.

${ }^{\text {vii }}$ Regression models were selected for presentation after examination of a correlation matrix (not reported).

${ }^{\text {viii }}$ We do not present regressions for the sub-sample of joint ventures as no variables were correlated with this category. 